\title{
A Case of Mucosal Contact Point Headache Caused by Septal Spur
}

\author{
Wonwoo Cho ${ }^{1}$, Tae Won Eom ${ }^{1}$, and Jeong Hong Kim ${ }^{2}$ \\ ${ }^{1}$ Medical Course, Jeju National University School of Medicine, Jeju; and ${ }^{2}$ Department of Otorhinolaryngology-Head and Neck Surgery, \\ Jeju National University School of Medicine, Jeju, Korea
}

비중격극에 의한 점막 접촉점 두통 1 예

조원우 ${ }^{1} \cdot$ 엄태원 ${ }^{1} \cdot$ 김정홍 ${ }^{2}$

제주대학교 의학전문대학원 의학사, ${ }^{1}$ 제주대학교 의학전문대학원 이비인후과학교실 ${ }^{2}$

Received November 5, 2013

Revised December 11, 2013

Accepted December 12, 2013

Address for correspondence

Jeong Hong Kim, MD

Department of Otorhinolaryngology-

Head and Neck Surgery,

Jeju National University

School of Medicine,

102 Jejudaehak-ro,

Jeju 690-756, Korea

Tel $+82-64-717-1716$

Fax +82-64-717-1029

E-mailsevent70@hanmail.net
Headaches attributed to disorders of the sinonasal region make their diagnosis and treatment sometimes challenging. Contact point between opposing mucosal surfaces in the nasal cavity can cause headache by a mechanism of referred pain in the distribution of trigeminal nerve. The most common anatomic abnormality of intranasal contact point is the diverse pattern of septal deviation in association with turbinate deformity or hypertrophy. In the absence of other pathological findings, the evaluation for intranasal contact points should be considered. We herein report that a patient, suffering from headache and periorbital pain refractory to medical treatment, experienced a complete abolition of pain after surgical correction of mucosal contact point in the nasal cavity. Korean J Otorhinolaryngol-Head Neck Surg 2014;57(6):407-10

Key Words Headache $\cdot$ Mucosal contact point $\cdot$ Septal spur.

\section{서 론}

두개 안면부 영역에서 통증을 호소하는 경우 임상 증상과 진단 검사 소견을 토대로, 원인 질환이 밝혀지지 않은 원발 두통과 원인 질환에 근거한 이차 두통, 그리고 뇌신경통과 중추성 원인의 안면통으로 분류하여 체계적인 치료를 도모 하고 있다. 시간적 연관성을 갖고 발생된 이차 두통의 경우 급, 만성 부비동염, 치아 및 턱관절 질환, 감염, 외상, 정신 질환, 그리고 얼굴 및 두개내 구조물의 해부학적 이상 등을 고려할 수 있으며 주로 삼차신경-혈관 복합체의 활성에 의해 다양 한 통증의 양상을 보이게 된다. 두경부의 영상학적 검사상 뇌와 비부비동내 혈관성, 염증성, 종물성 병변이 관찰되지 않 으면서 국소신경학적으로 이차 두통을 의심할 만한 원인을 찾을 수 없고, 편측성으로 특정 안면 부위에 지속되는 통증과 압박감을 호소하는 경우에는 비강내 특정 부위 점막의 접촉 점에 의한 통증을 염두에 두고 세심한 관찰이 필수적으로 요
구된다. 이에 저자들은 안와 통증과 동반하여 반복적인 두 통을 호소하는 환자에서 비강내 심한 비중격극에 의한 점막 접촉성 두통을 의심하여 임상적 진단 후 수술적 치료로 두통 을 비롯한 안면부 통증이 완전 소실된 환자 1 예를 경험하였 기에 문헌 고찰과 함께 보고하고자 한다.

\section{증 례}

16세 여자 환자로 약 3년 전부터 좌측 안면부, 특히 눈 내 측 주위와 광대빼 주변의 뺨이 저리는 듯한 이상 감각과 통 증을 간헐적으로 호소하다가 서서히 통증 지속 시간이 길어 지고 진통제를 복용하여도 잠깐만 호전되었다가 다시 악화 되는 일이 반복되면서 내원 7개월 전부터는 학업과 시험 같은 신경성 스트레스를 받을 때 참기 힘들 정도의 안와 및 두개 안면부 통증을 주소로 내원하였다. 편두통이 의심된다고 하 여 신경과 외래에서 저용량 amitriptyline과 gabapentine 제제 
로 단기간 약물 치료를 시행하였으나 통증이 호전되는 양상 은 없었다. 부비동염으로 인해 두통과 안면통이 생길 수 있다 고 들어 이비인후과는 처음 방문하였으며 진찰 소견상 경도 의 간헐적인 코막힘 증상 외에 오심, 구토, 광선공포증, 알레르 기성 비염 및 후비루 증상은 호소하지 않았다. 안면통의 강도 는 10점 Visual Analogue Scale(VAS)을 이용한 측정에서 9 점(통증 없는 상태 0점, 통증이 가장 심한 상태 10점)이라고 답하였고, 과거력상 코 외상을 입은 기억은 없었으며 가족력 도 없었다. 좌측 비내시경 소견상 비점막을 수축시키기 전에 는 하비갑개 비후증 소견 외에 특이 이상 소견은 관찰되지 않 았으나 비점막 수축제를 적신 거즈를 패킹하고 나서 제거 후 시행한 비내시경 검사상 좌측 비중격 후방 골부에서 돌출한 뼈 돌기가 좌측 하비갑개 후방부와 접촉하면서 점막을 강하게 누르고 있는 양상이 관찰되었다(Fig. 1). 한편, 우측 비강은 특 이 해부학적 이상 소견이 관찰되지 않았다. 부비동 전산화단 층촬영검사상 부비동염이나 종물 소견은 관찰되지 않았으며 구조적 이상으로 좌측 비중격극이 하비갑개와 맞닿아 있는 소견이 관찰되었다(Fig. 2). 진단을 위한 검사로 $10 \%$ 리도케

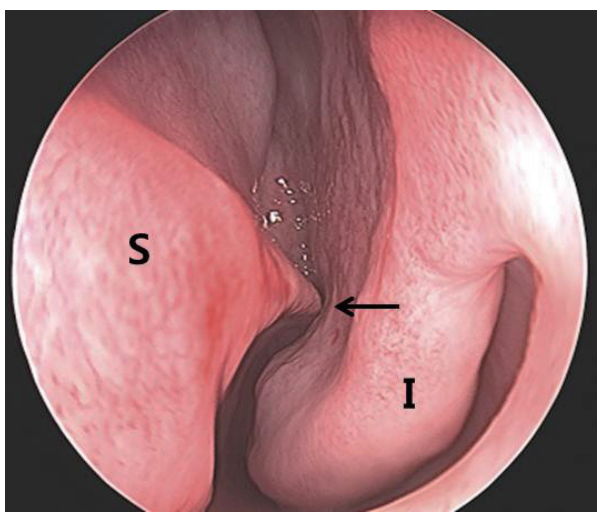

Fig. 1. Nasal endoscopy reveals the mucosal contact point (black arrow) between nasal septum and left inferior turbinate. S: septum, I: inferior turbinate.
인 용액을 적신 작은 거즈를 비중격극과 맞은편 하비갑개 사 이에 패킹 후 5 분 경과 후 제거하고 나서 통증의 양상을 확인

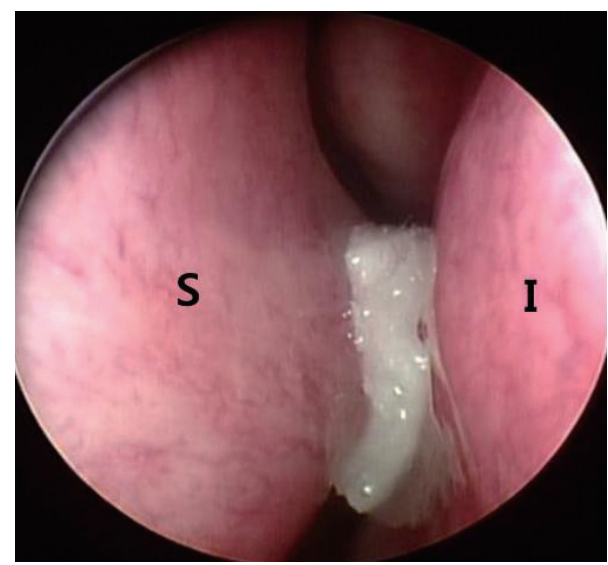

Fig. 3. Nasal endoscopic view after application of $10 \%$ lidocainesoaked cotton pledget at the contact point. The patient experienced the significant improvement of facial pain after cotton pledget removal in 5 minutes. S: septum, I: inferior turbinate.

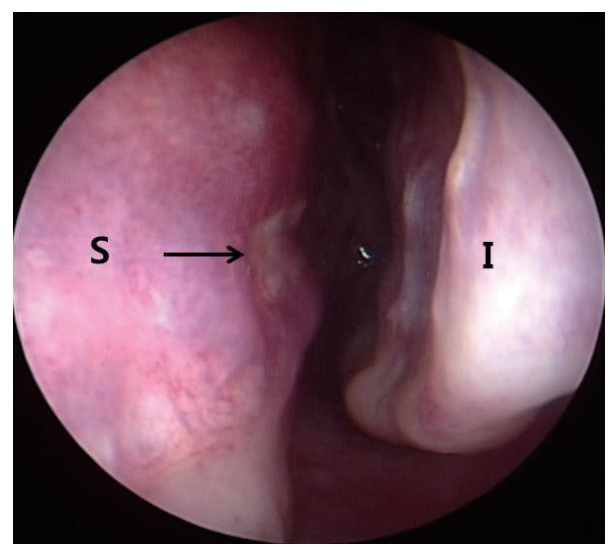

Fig. 4. The patient underwent the septoplasty and outfracturing of inferior turbinate. The septal spur was completely removed (black arrow) and the left inferior turbinate was enough detached from the septum. This picture was taken on postoperative 1 month. S: septum, I: inferior turbinate.

Fig. 2. Preoperative paranasal sinus computed tomography scan shows the contact point (white arrows) between nasal septum and left hypertrophied inferior turbinate. The inflammatory mucosal change of paranasal sinuses and other anatomical deformities are not noted. Axial view (A) and coronal view (B).
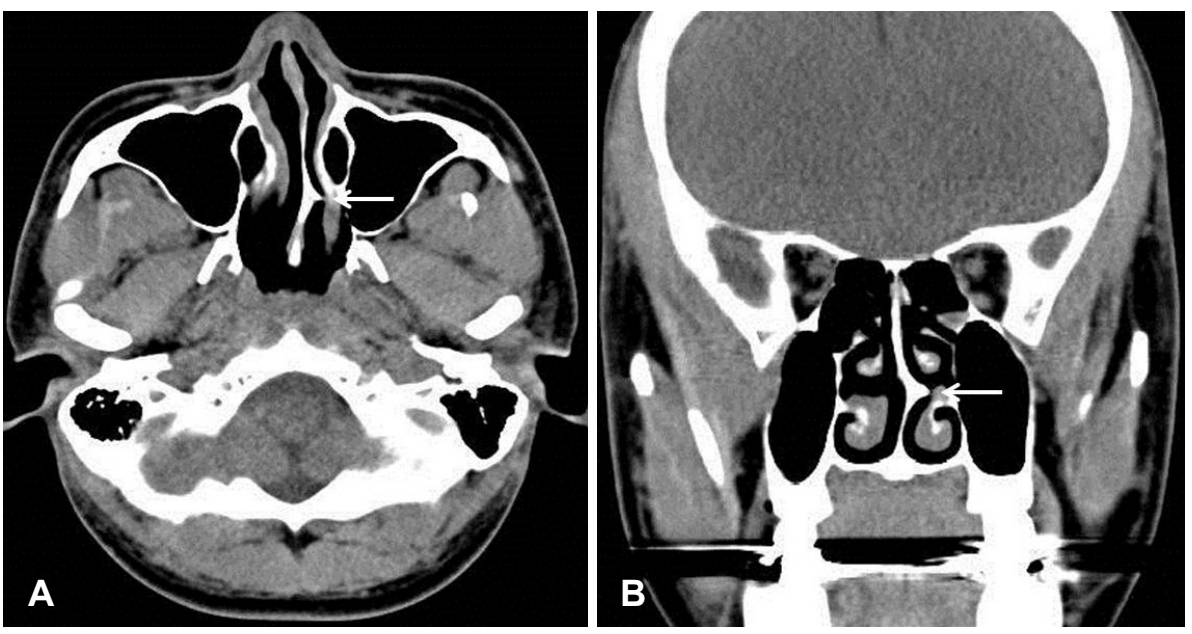
한 결과 VAS scale상 3점으로 일시적인 통증 완화를 경험하 였다(Fig. 3). 점막 접촉성 두통 의심하에 통증의 완전한 제거 를 목적으로 전신 마취하에 비중격 교정술 및 하비갑개 외측 편향술을 시행하였으며, 수술 2일째 비강 패킹을 제거한 후 안면부 통증의 정도는 처음 내원시 느겼던 통증 양상과는 달 리 VAS scale상 1점이라 답하였고 수술 후 비중격 점막 손상 으로 인한 경도의 통증만을 호소하였다. 수술 후 1 주일이 경과 하면서 안면부 통증은 거의 사라졌으며 수술 후 1 개월째 점막 치유는 거의 정상화되었고(Fig. 4), 2년 경과 후 외래 방문시 안 면부 통증이나 안와 불편감, 두통은 호소하지 않았고 접촉점이 다시 형성된 소견 또한 관찰되지 않았다.

\section{고 찰}

두통을 동반한 안면통이 눈, 코, 협부 또는 부비동의 특정 부위에 국한되어 나타나는 경우 흔히 그 부위의 질환을 원인 으로 생각하게 된다. 확진은 각 부위의 원인 질환이 치료될 때 통증이 경감하거나 소실되는 경우에 가능하다. 원인 질환 이 존재하는 이차 두통은 전체 두통의 $10 \%$ 미만이지만 원인 의 특성에 따라 신경계 후유증이 심하거나 응급상황을 초래 하는 경우가 많아 신중한 접근 및 정확한 진단이 필요하다. ${ }^{1)}$ Clerico $^{2)}$ 는 접촉점 두통의 병태생리에 대해 부비동염이 없는 경우에도 기계적, 화학적, 온도 자극에 의해 비점막에 분포하 는 삼차 신경이 자극되면서 substance P가 방출되고 구심성 통증 신호를 유발하여 시상과 대뇌에 도달함으로써 두통을 인식한다고 처음 보고하였다. 최근 연구에서는 삼차 신경-혈 관복합체의 활성에 의해 substance P 외에 칼시토닌유전자관 련펩티드(calcitonin gene related peptide), 혈관작용장펩티 드(vasoactive intestinal polypeptide), neurokinin $\mathrm{A}$ 와 같은 신경펩티드의 방출이 삼차신경 말단에서 증가하여 혈관확장, 비만세포의 탈과립화, 혈장 단백의 삼출과 같은 염증반응이 동 시에 일어나면서 통증이 유발되고 특히 삼차 신경의 제 1,2 분 지로부터 유래된 유수신경섬유(myelinated fiber)인 구심성 침 해수용성(nociceptive) C 신경섬유가 탈수초화(demyelination) 되는 과정에 활동전위가 발생하여 통증유발점으로부터 떨어 진 곳에서도 연관통으로 중추신경계로 통증을 전달하는 것으 로 보고되었다. ${ }^{3)}$ 2004년 국제두통분류(International Classification of Headache Disorder, ICHD-2)에서는 점막 접촉성 두통을 이차 두통 범주에 포함시켰고, 안구 주위, 내안각 혹은 측두관골 부위에 간헐적인 국소 통증과 비내시경 혹은 전산 화단층촬영상 급성 부비동염의 소견 없이 점막 접촉점의 존 재가 명시화되어야 하고, 1) 자세 변경을 통한 중력변화에 따른 점막 충혈과 상응하는 통증과, 2) 접촉점에 국소 마취 적용 후
5 분 이내 통증이 경감하고, 3) 접촉점의 제거 후 7일 이내에 의 미 있는 호전을 보이는 경우 중 적어도 한 가지에 충족될 경우 로 한정하였다. ${ }^{4}$ 그러나 2013년 국제두통분류(ICHD-3rd edition, beta version)에서는 점막 접촉성 두통이라는 독립적 명 칭의 분류 대신 비점막, 비갑개, 비중격의 질환에 기인한 두통 으로 분류하면서 비내시경 혹은 전산화단층촬영상 비강내 수 포성 비갑개(concha bullosa) 혹은 비중격극(septal spur)과 같 은 구조가 존재하고, 1) 비강 병변의 발현과 밀접한 시간적 연 관성을 가지고 두통이 발생하며, 2) 비강 병변의 개선 혹은 악 화와 동반하여 증상이 의미 있게 호전되거나 악화되고, 3) 병 변 부위에 국소 마취제 도포 후 두통이 의미 있게 경감하고, 4) 두통이 병변과 같은 쪽에 존재하는 경우 중 적어도 두 가지를 충족할 때로 정의를 내렸다. ${ }^{5)}$

이웃한 비강 점막의 접촉에 의한 안면부 통증은 눈 주변, 특히 안구 상부와 내측에 주로 통증을 호소하고 협부와 측 두골 주변으로 번지는 양상을 띄며 편측성이면서 간헐적이 고, 때때로 비강 증상, 특히 비폐색을 동반하여 나타난다. ${ }^{6}$ 비 강내 접촉점을 발생시킬 수 있는 구조적 이상으로는 비중격 편향(deflection), 비틀림(buckling), 극돌기(spur)에 의한 만 곡증이나 양측 혹은 편측 수포성 비갑개(concha bullosa), 역 곡중비갑개(paradoxical middle turbinate), 과함기화된 상비 갑개와 같은 비갑개의 변형, 그리고 확장된 비제봉소, 과함기 화된 사골봉소, 비강내 비석(rhinolith), 변형된 구상돌기 등의 가능성이 있지만 아직은 두통의 직접적인 유발 요인으로 충 분히 증명되어 있지는 않다. ${ }^{7)}$ 비강 점막의 접촉점에 의한 통 증은 연구자들마다 다른 진단 및 치료 결과를 주장하고 있 어 아직도 논쟁의 여지가 많다. Bieger-Farhan 등은 100 명 의 환자 중 전산화단층촬영 결과상 접촉점을 보였던 55 명의 환자군에서 안면통과 두통이 항상 동반되어 있지는 않다고 하였고 오히려 비폐색이나 후각저하, 부비동 혼탁 정도의 심화 와 연관성이 있는 것으로 보고하였다. 접촉점에 의한 안면부 통증의 진단에 있어서 가장 중요한 것은 충분한 병력 청취와 자세한 문진을 통해 비성(rhinogenic) 두통 외의 원인 가능성 을 최대한 배제하고 내시경적 검사와 전산화단층촬영을 통 해 염증성, 종물성 병변이 없음을 인지한 후 접촉점 유무를 면밀히 조사하고 의심 부위에 국소 마취도포를 통해 통증이 $50 \%$ 이상 경감하는지를 반드시 확인해 보아야 한다. ${ }^{9}$ 국소 마 취 후 5 분 이내 통증의 변화가 나타나지 않으면 수술적 치료 의 대상이 아니라고 판단해야 한다. 하지만 비강내 접근이 어 려운 부위인 사골동-비중격 혹은 상비갑개-비중격 사이는 국소마취 주사나 도포가 현실적으로 어려운 점이 있어 정확 한 진단을 내리기가 더욱 쉽지 않다. 접촉점이 의심되고 이로 인한 접촉점 두통이라고 진단이 내려지더라도 우선 치료 전 
략은 말초에서 substance P에 의한 통증 중재를 선택적으로 차단하는 capsaicin 제제나 삼차 신경 말단부에 분포하는 $5-\mathrm{HT}_{1 \mathrm{~B} / \mathrm{D}}$ 에 선택적으로 작용하는 triptan 제제, 그리고 항우 울제인 amitriptyline과 같은 내과적 치료를 단기간 사용하는 것이 선행되어야 하고, 효과가 없다고 판단될 때 비로소 수술 적 치료를 계획한다. ${ }^{10,11}$ 물론 수술적 치료는 접촉점을 분리 해 주는 모든 술식, 예를 들면 비중격성형술, 비갑개 점막하 절제술 및 외향 골절술, 내시경적 접촉점 제거술 등 모든 비 과 영역의 수술이 적용 가능한데, 비강내 접촉점의 제거시 통 증이 완전히 없어진다는 보고도 있지만 연구자에 따라 술 후 증상의 호전 혹은 증상 완화가 50 80\% 정도의 성공률을 보 인다고 보고하고 있다. ${ }^{12-14)}$ 결국 접촉점 외에 다른 원인에 의 한 두통을 감별하지 못하거나 정확한 수술적 치료를 시행하지 못해 경과 관찰 기간 중에 다시 접촉점이 형성되는 데서 나온 차이라고 해석된다. 한편, Abu-Bakra와 Jones ${ }^{15}$ 의 연구에서 는 안면통과 접촉점을 가진 18 명의 환자군 중 14 명에서 수술적 치료를 시행하지 않고 저용량의 amitriptyline으로 증상 호전 을 도모할 수 있었다고 하여 안면통과 접촉점의 존재는 인과 관계가 아니라 우연히 발견된 것이고 수술적 치료는 위약 효과 로 일시적으로 통증이 호전되는 것일 뿐이라고 주장하였다.

결론적으로 안면통 혹은 두통을 호소하는 환자에서 신경혈관학적 문제 외에 비부비동 질환에 의한 가능성을 염두에 두고 수술적 치료에 착수하기 전 충분한 진단적 검사와 약물 요법을 시행하는 것이 중요하고, 아직까지는 접촉점의 제거만 이 유일한 치료법이라는 것을 입증할 이론적 근거가 미약하 므로 수술 후 적어도 1년 이상의 충분한 경과 관찰 기간을 두 고 전향적 이중맹검통제연구(prospective double-blind controlled study)를 통해 접촉점의 제거가 통증 경감 혹은 완전 한 치유를 위한 하나의 결정 인자임을 명확히 하는 것이 중 요하다 하겠다.

\section{Acknowledgments}

This research was supported by the 2014 scientific promotion program funded by Jeju National University.

\section{REFERENCES}

1) Welge-Luessen A, Hauser R, Schmid N, Kappos L, Probst R. Endonasal surgery for contact point headaches: a 10-year longitudinal study. Laryngoscope 2003;113(12):2151-6.

2) Clerico DM. Sinus headaches reconsidered: referred cephalgia of rhinologic origin masquerading as refractory primary headaches. Headache 1995;35(4):185-92.

3) Stammberger H, Wolf G. Headaches and sinus disease: the endoscopic approach. Ann Otol Rhinol Laryngol Suppl 1988;134:3-23.

4) Headache Classification Committee of the International Headache Society. The International Classification of Headache Disorders, 2nd ed. Cephalalgia 2004;24(Suppl1):1-160.

5) Headache Classification Committee of the International Headache Society (IHS). The International Classification of Headache Disorders, 3rd edition (beta version). Cephalalgia 2013;33(9):629-808.

6) Harrison L, Jones NS. Intranasal contact points as a cause of facial pain or headache: a systematic review. Clin Otolaryngol 2013;38(1): $8-22$.

7) Bektas D, Alioglu Z, Akyol N, Ural A, Bahadir O, Caylan R. Surgical outcomes for rhinogenic contact point headaches. Med Princ Pract 2011;20(1):29-33.

8) Bieger-Farhan AK, Nichani J, Willatt DJ. Nasal septal mucosal contact points: associated symptoms and sinus $\mathrm{CT}$ scan scoring. Clin Otolaryngol Allied Sci 2004;29(2):165-8.

9) Mohebbi A, Memari F, Mohebbi S. Endonasal endoscopic management of contact point headache and diagnostic criteria. Headache 2010; 50(2):242-8.

10) Cady RK, Dodick DW, Levine HL, Schreiber CP, Eross EJ, Setzen $\mathrm{M}$, et al. Sinus headache: a neurology, otolaryngology, allergy, and primary care consensus on diagnosis and treatment. Mayo Clin Proc 2005;80(7):908-16.

11) Tosun F, Gerek M, Ozkaptan Y. Nasal surgery for contact point headaches. Headache 2000;40(3):237-40.

12) Behin F, Behin B, Bigal ME, Lipton RB. Surgical treatment of patients with refractory migraine headaches and intranasal contact points. Cephalalgia 2005;25(6):439-43.

13) Giacomini PG, Alessandrini M, DePadova A. Septoturbinal surgery in contact point headache syndrome: long-term results. Cranio 2003; 21(2):130-5

14) Harley DH, Powitzky ES, Duncavage J. Clinical outcomes for the surgical treatment of sinonasal headache. Otolaryngol Head Neck Surg 2003;129(3):217-21.

15) Abu-Bakra M, Jones NS. Prevalence of nasal mucosal contact points in patients with facial pain compared with patients without facial pain. J Laryngol Otol 2001;115(8):629-32. 